\title{
Karbon Nanotüp (CNT) Ve Nano Grafen (G) Takviyeli Al 2024 Kompozitlerin Vorteks Yöntemiyle Üretilerek Așınma Ve İșlenebilme Özelliklerinin İncelenmesi
}

\section{Investigation Of Abrasion And Machining Properties Of Carbon Nanotube (CNT) And Nano Grafen (G) Reinforced AI 2024 Composites By Vortex Method}

\author{
Muharrem Pul \\ Kırıkkale Üniversitesi, Kırlkkale Meslek Yüksekokulu, 71450 KIRIKKALE
}

Başvuru/Received: 10/09/2018

Kabul/Accepted: 25/12/2018

Son Versiyon/Final Version: 31/01/2019

\section{Öz}

Günümüzde metaller gibi klasik malzemelerin birçok özellikleri gelişen teknolojinin ihtiyaçları için yeterli olamayınca, daha üstün özelliklere sahip olan kompozit malzemeler üretilmeye başlanarak bu konuda hızlı bir gelişme sürecine girilmiştir. Klasik malzemelere göre kompozit malzemelerin en belirgin özellikleri hafiflik ve sağlamlıklarıdır. Yapılan araştırma ve geliş̧tirmeler neticesinde, bu malzemelerin çekme, darbe dayanımlarının artıılması; yorulma, kimyasal direnç ve elektrik özelliklerinin iyileştirilmesi mümkün olmuş ve kompozit malzemeler yaygın şekilde havacılık, deniz taşıtları, otomotiv, makine, inşaat, askeri ve uzay teknolojisi alanlarında kullanılmaya başlanmıştır. Son yıllarda geliştirilen bu tür kompozitlerin arasında nano katkılı metal matrisli kompozitler yer almaya başlamıştır. Bu çalışmada nano malzeme katkılı Al 2024 kompozitler üretilmiştir. Kompozitlerin üretim yöntemi olarak Vorteks (karıştırmalı döküm) yöntemi kullanılmıştır. Al 2024 içerisine farklı oranlarda (\%0,5-\%1,0-\%2,0-\%4,0) karbon nanotüp (CNT)ve nano boyutta grafen $(\mathrm{G})$ takviye edilmiştir. Üretilen alüminyum kompozitlerin mikroyapıları incelenerek, mekanik özelliklerini tespit etmek amacıyla sertlik ve aşınma deneyleri yapılmıştır. İşlenebilirlik deneyleri; $200 \mathrm{~m} / \mathrm{min}$ kesme hızında, $0,10-0,15$ ve $0,30 \mathrm{~mm} / \mathrm{dev}$ ilerleme değerlerinde ve $1,0 \mathrm{~mm}$ sabit kesme derinliğinde yapılmıştır. İşleme deneyleri sırasında kompozit malzemelerin yüzey pürüzlülükleri ölçülmüsstür. Ayrıca kesici takımların aşınmalarını belirlemek için mikroskop görüntüleri çekilmiştir. Deneyler sonucunda elde edilecek verilere göre kompozit yapı içerisindeki nano malzeme miktarlarının optimum değerleri belirlenmiştir.

\section{Anahtar Kelimeler}

“Al 2024, Karbon Nanotüp, Nano Grafen, İşlenebilirlik, Aşınma”

\begin{abstract}
The most obvious characteristics of composite materials compared to conventional materials are lightweight and durability. In research and development as a result, shrinkage of these materials, to increase the impact resistance; fatigue, improved chemical resistance and electrical properties of composite materials has been widely possible and aviation, watercraft, automobile, machinery, construction, military and space technology has been used in the field. Among these composites developed in recent years, nanocomposite metal matrix composites have begun to take place.In this study, N 20 material composites are produced. Vortex (stirr casting) method was used as the production method of composites. Carbon nanotube (CNT) and nano-sized graphene $(\mathrm{Gr})$ were reinforced in different ratios (0.5\%-1.0\% - 12.0\% - 4.0\%) in $\mathrm{Al} 2024$. The microstructures of the aluminum composites were examined and hardness and abrasion tests were performed to determine their mechanical properties. Machinability tests, $200 \mathrm{~m} / \mathrm{min}$ at a cutting speed of $0.10-0.15$ and $0.30 \mathrm{~mm} / \mathrm{rev}$ at feed rate and $1.0 \mathrm{~mm}$ of constant cutting depth was made. Surface roughness of composite materials was measured during machining experiments. In addition, microscope images were taken to determine the abrasion of the cutting tools. According to the data obtained as a result of the experiments, the optimum values of the amount of nano material in the composite structure were determined.
\end{abstract}

\section{Key Words}

“AI 2024, Carbon nanotube, Graphene Nanoplathelet, Machinability, Abrasion” 
Hafif metal esaslı kompozitler, tıp, savunma sanayi, otomotiv, havacılık, enerji, altyapı, denizcilik, ulaştırma v.b. pekçok sektörde giderek artan oranda uygulama sahası bulmaktadır. Son zamanlarda bu tür kompozitlerin geliştirilmesinde kullanılan katkı maddeleri daha çok nano boyutta malzemeler olmaktadır. Bu malzemeler içerisinde nano boyuta $\mathrm{B}_{4} \mathrm{C}, \mathrm{SiC} \mathrm{Al}_{2} \mathrm{O}_{3}, \mathrm{MgO}$, karbon nano tüpler (CNT) ve grafen $(\mathrm{G})$ gibi malzemeler ön plana çıkmaktadır. Günümüzde daha ekonomik, daha hafif ve gelişmiş mekanik özellikler sağlayan bu tür kompozitler üzerine yapılan araştırmalarda hız kazanmıştır.

Alüminyum alaşımları, düşük yoğunluk ve yüksek mekanik özelliklerinden dolayı otomotiv, havacılık ve savunma sanayi gibi birçok önemli üretim alanında kullanımları hızla artmaktadır. Duralümin olarak da bilinen 2024 Al-alaşımı, alüminyum alaşımları arasında en sert, elastisite modülü ve mukavemet değerleri en yüksek olanlarından biridir. Spesifik mukavemet (akma gerilmesi/ yoğunluk) ve spesifik elastisite modülünün (elastisite modülü/yoğunluk) önemli olduğu yerlerde, otomotiv sanayinde, vagon yapımında, mühimmat sanayinde, uçak gövde ve kanatlarında, ortopedik taban, perçin ve çekici tekerlekleri yapımında yaygın olarak kullanılmaktadır (Aydın, Bayram 2010). Alüminyum ve alaşımlarının çok yaygın olarak kullanılmasının sonucunda, kompozit malzemelerin bir türü olan metal matrisli (esaslı) kompozitlerin üretiminde alüminyum en yaygın kullanılan metallerden biri haline gelmiştir. Alüminyum ve alaşımları bu tip kompozitlerde ana eleman (matris) olarak yer almaktadır. Kompozitlerde matris malzemesi kadar önemli olan diğer elemanlar takviyelerdir. Takviye malzemeleri kompozitin teknik özelliklerini belirleyen en önemli unsurdur. Son yıllarda, $\mathrm{Al}_{2} \mathrm{O}_{3}, \mathrm{SiC}, \mathrm{B}_{4} \mathrm{C}, \mathrm{TiB}_{2}, \mathrm{TiC}, \mathrm{WC}, \mathrm{W}, \mathrm{C}, \mathrm{MgO}$ gibi seramik esaslı takviyelerin yanında nano boyutta malzemelerde kompozit yapılar içerisine takviye edilmeye başlanmıştır. Bu nano malzemelerin en önemlileri arasında karbon esaslı grafen ve karbon nanotüp sayılmaktadır.

Grafenkarbon esaslı bir malzeme olup bir atom kalınlığında, bal peteği şeklinde örgülü yapıya sahiptir. Bu altıgen yapı garafenin katmanlı şeklinin tek katmanını oluşturmaktadır. Ayrıca grafen; süper esnek, süper sağlam, süper hafif ve süper ince bir malzeme olup, günümüzdeki en heyecan verici bilimsel gelişmelerinden biri olarak görülmektedir (Şenel, Gürbüz, Koç 2015). Grafen, bir atom kalınlığında karbon tabakasıdır. Üst üste 3 milyon tabakadan oluştuğu ve $1 \mathrm{~mm}$ yakın bir kalınlığında olduğu hesaplanmaktadır. Elastik ve esnek olması yanında aynı zamanda çok serttir ve çelikten yüzlerce kez daha kuvvetlidir. Çok iyi elektrik iletkenidir ve erime noktası $3000 \mathrm{C}^{\circ}$ civarındadır. Grafen, düz plakalar ve bir atom kalınlığı olan, atomları bir bal tarağı yapısında bulunan bir karbon formudur. Grafen son zamanlarda mekanik, elektriksel ve termal uygulamalardaki mükemmel performansından dolayı önemli akademik ve endüstriyel ilgi çekmektedir. Grafen, metal kompozitlerinde iyi bir takviye oluşturan olağanüstü mekanik özelliklere sahiptir (Dharsan, Kumar 2017). Tablo 1'de grafene ait bazı teknik özellikler verilmiştir.

Tablo1. Grafenin mekanik ve fiziksel özellikleri [4]

\begin{tabular}{ll}
\hline Property & Graphene \\
\hline Tensile Strength & $130 \mathrm{Gpa}$ \\
Elastic modulus & $0.5-1 \mathrm{Tpa}$ \\
Thermal conductivity & $5.3 \times 103 \mathrm{Wm}-1 \mathrm{~K}-1$ \\
Co efficient of thermal expansion & $-6 \times 10-4 / \mathrm{K}$ \\
Specific surface area & $2630 \mathrm{~m}^{2} \mathrm{~g}^{-1}$ \\
Electron mobility & $1500 \mathrm{~cm}^{2} \mathrm{~V}^{-1} \mathrm{~s}^{-1}$ \\
Transmittance & $>95 \%$ for $2 \mathrm{~nm}$ thick film \\
& $>70 \%$ for $10 \mathrm{~nm}$ thick film \\
\hline
\end{tabular}

Karbon nanotüpler (CNT), 1990’lı yılların başından itibarenolağanüstü özelliklerinin farkedilmesi ile yoğun olarak araştırmalara konu olmuş ve giderek bu alaka, CNT'ninbaşta nanobilim olmak üzere çok sayıda farklı alanlarda bir "fenomene"e dönüşmüştür. Hem deneysel hem de teorik birçok çalışmada CNT'ler, nanoteknoloji için bir model olmuştur. Bu alandaki ilerlemeler oldukça çarpıcı olmuştur vebu malzemelerin bir özelliğinin keşfi, bu özellikten yola çıkan bir uygulamanın geliştirilmesi ve son olarak da uygulamanın ticari ürüne dönüşmesi ile sonuçlanamaktadır. Günümüzde, konu üzerinde dünya çapındayapılan sayısız araştırmanın yanında birçok dev şirket CNT esaslı ürünleri piyasaya sürmede birbiriyle yarışmaktadır. Tablo 2'de tek ve çok duvarlı karbon nano tüplere ait bazı teknik özelikler verilmiştir.

Tablo 2. Tek ve çok duvarlı karbon nano tüplere teknik özelikler

\begin{tabular}{l|l|l}
\hline Properties & SWCNTs & MWCNTs \\
\hline Specific Gravity & $0.8 \mathrm{~g} / \mathrm{cm}^{5}$ & $1.8 \mathrm{~g} / \mathrm{cm}^{3}$ \\
Elastic Modulus & $\sim 1 \mathrm{TPa}$ & $\sim 0.3-1 \mathrm{TPa}$ \\
Strength & $50-500 \mathrm{GPa}$ & $10-60 \mathrm{GPa}$ \\
Resistivity & $5-50 \mu \Omega \mathrm{cm}$ & $5-50 \mu \Omega \mathrm{cm}$ \\
Thermal Conductivity & $3000 \mathrm{~W} \mathrm{~m} \mathrm{~K}^{-1}$ & $3000 \mathrm{Wm} \mathrm{K}^{-1}$ \\
Thermal Stability & $>700{ }^{\circ} \mathrm{C}$ (in air); & $>700^{\circ} \mathrm{C}$ (in air); \\
& $2800^{\circ} \mathrm{C}$ (in vacuum) & $2800^{\circ} \mathrm{C}$ (in vacuum) \\
Specific Surface Area & $\sim 400-900 \mathrm{~m}^{2} / \mathrm{g}$ & $\sim 200-400 \mathrm{~m}^{2} / \mathrm{g}$ \\
\hline
\end{tabular}

CNT'ler, diger tüm 1B nano malzemeler içerisinde belki de en büyük öneme sahip olanlardır. CNT, en basit manada, nanometre çaplı, $\mu \mathrm{m}$ boylu borusal yapılardır. Diger bir ifade ile CNT'ler, yapısal açıdan bakıldığında, tek ya da daha çok grafen (grafitin tek bir katmanı) levhadan yapılı, içiboş bir silindir gibi hayal edilebilir (Şekil 1). Söz konusu silindirin çapı 0,4 nm'den $100 \mathrm{~nm}$ ya da daha yüksek değerlere kadar çıkabilir. Bununla birlikte 15 nm'nin üstündeki çaplara sahip borusal yapıların "karbon 
nanolif" olarak sınıflandırılmasını önermiştir. Üretim yöntemi ve şartlarına baglı olarak çok farklı olabilen CNT'lerin boyları ise yüzlerce $\mu$ m'den cm mertebesine kadar çıkabilir (Mutlay 2014).

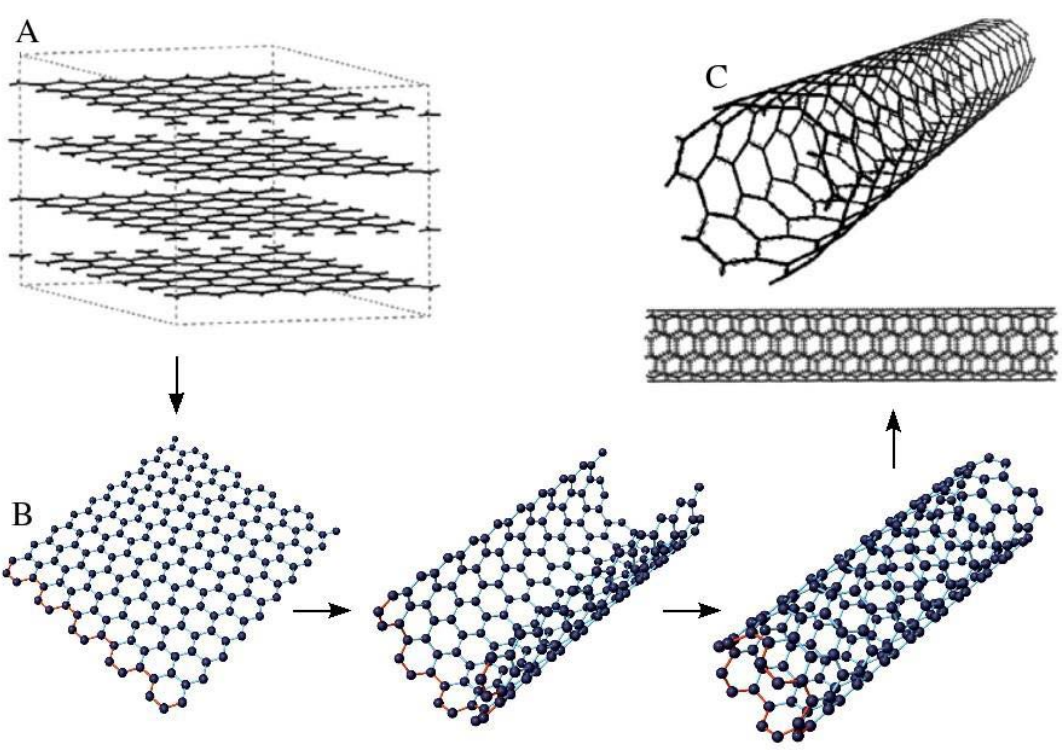

Şekil 1. (A) grafit, (B) grafen levha ve (C) karbon nanotüp

Karbon alanında yapılan araştırmalar, 1991'de Iijima tarafından karbon nanotüpleri (CNT) keşfi ile devrim yaratmıştır. Deneyler ve simülasyonlar CNT'lerin karbon elyaflarına göre olağanüstü mekanik özelliklere sahiptir. CNT'lerin 1000 GPa'ya kadar sertlik, $100 \mathrm{GPa}^{\prime} l 1 \mathrm{k}$ mukavemet ve $6000 \mathrm{~W} \mathrm{~m}^{-1} \mathrm{~K}^{-1}$ kadar 1 sıl iletkenlik değerlerine sahip olduğu görülmüştür. Bu araştırmalar, CNT'lerin, insanlığın bildiği, olağanüstü özelliklere sahip en güçlü elyaf olduğunu göstermektedir (Bakshi, Lahiri, Agarwal 2010).

Yapılan literatür araştırmasında nano malzeme katkısının Al 2024 alaşımının özelliklerini olumlu yönde geliştireceği öngörülmektedir. Kompozit malzemelerin kullanım alanı mühendislik uygulamalarında büyük bir yer teşkil etmektedir. Özellikle havacılık, makine, savunma, ulaştırma, otomotiv gibi sektörler kompozit malzemelerin kullanımının çok yaygın olduğu alanlardır. Bu projenin diğer bir amacı da bu sektörlerde metalik malzemelere alternatif oluşturabilecek yeni bir nanomalzeme katkılı kompozit geliştirmektir. Ayrıca bu çalışmanın sonucunda elde edilecek veriler 1şığında yeni çalışmaların önünün açılacağı ve daha üstün özelliklerde kompozitlerin geliştirilebileceği düşünülmektedir. Yapılan ön araştırmada nano malzeme katkılı metalik kompozitler üzerine yeterince yerli araştırma ve yayın olmadığı da ayrıca tespit edilmiştir. Bu bağlamda, yapılacak olan proje ve çıkartılacak yayınlar ile literatüre katkı yapılması da ayrıca hedeflenmektedir.

\section{MATERYAL VE YÖNTEM}

$\mathrm{Bu}$ proje çalışmasında ana malzeme (matris malzemesi) olarak Al 2024 alaşımı seçilmiştir. Kompozit ana malzemesi olan Al 2024 alşımına ait özellikler Tablo 3’te verilmektedir.

Kimyasal Bileşim

Tablo 3. Al 2024 alaşımının teknik özellikleri

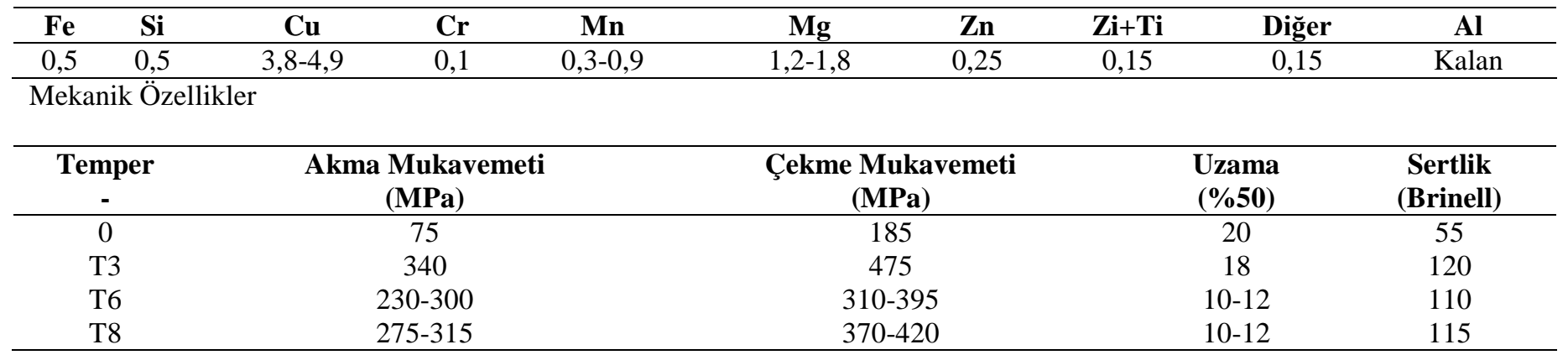

Kompozitlerin hazırlanmasında takviye elemanı olarak kullanılacak olan nano malzemeler Tablo 4'te, verilmiştir.

Tablo 4.Nano malzemeler

\begin{tabular}{lcc}
\hline Nano malzeme cinsi & İçerik & Boyut \\
\hline Karbon Nanotüp (CNT) & $\% 95$ saflıkta & $10-20 \mathrm{~nm}$ \\
\hline
\end{tabular}


Nano Grafen (G)

$\% 99,5$ saflikta

$6-16 \mathrm{~nm}$

Proje çalışmasına kompozit malzemelerin hazırlanmasıyla başlanmıştır. Her nano malzemeden dört farklı katkı oranı kullanılarak toplamda 8 farklı özellikte nano malzeme katkılı Al 2024 nano kompozitin üretilmiştir. Üretilen kompozit malzemelerin takviye oranları Tablo 5'te verilmektedir.

Tablo 5.Al 2024 matrisli kompozitlerin nano malzeme katkı oranları

\begin{tabular}{lllc}
\hline \multicolumn{2}{c}{ KARBON NANOTÜP (CNT) } & \multicolumn{2}{c}{ NANO GRAFEN (G) } \\
\hline Numune 1 & Al 2024+\%0,5 CNT & Numune 5 & Al2024+\%0,05 G \\
Numune 2 & Al 2024+\%1,0 CNT & Numune 6 & Al2024+\%1,0 G \\
Numune 3 & Al 2024+\%2,0 CNT & Numune 7 & Al2024+\%2,0 G \\
Numune 4 & Al 2024+\%4,0 CNT & Numune 8 & Al2024+\%4,0 G \\
\hline
\end{tabular}

Kompozit numunelerin elde edilmesinde sıvı faz yöntemlerinden olan karıştırmalı döküm yöntemi kullanılmıştır. Bu amaçla deney numunelerinin hazırlanması için laboratuvar tipi düşük pota kapasitesinde bir adet karıştırmalı döküm deney aparatı yaptırılmıştır. Yaptırılan ve karıştırmalı döküm deneylerinde kullanılan aparata ait görüntü Şekil 2'de verilmiştir.

Pota içerisine konulan Al 2024 matris malzemesi $750^{\circ} \mathrm{C}-800^{\circ} \mathrm{C}$ sıcaklık aralığına kadar ısıtılarak erimiş sıvı metal elde edilmiştir. Daha sonra sıvı metal içerisine nano malzemeler katkılanarak, 500 dev/dak hızda yaklaşık 10 dakika süre ile karıştırılmıştır. Karıştırma işleminden sonra sıvı metal önceden hazırlanan kalıplar içerisine dökülerek katılaşmaya bırakılmıştır. Tamamen soğuyup katılaşan kompozit numuneler, boru şeklindeki yuvarlak kalıp içerisinden tornalanmak suretiyle çıkarılmışlardır. Üretilen nano malzeme takviyeli kompozit numunelere ait toplu görüntü Şekil 3'te verilmektedir.

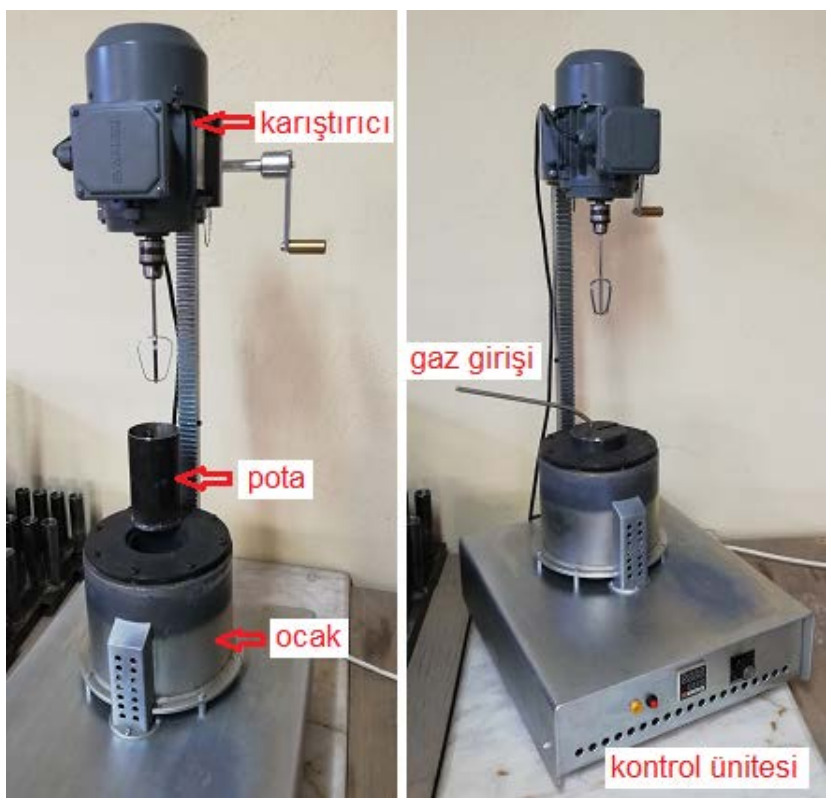

Şekil 2. Karıştırmalı döküm aparatı

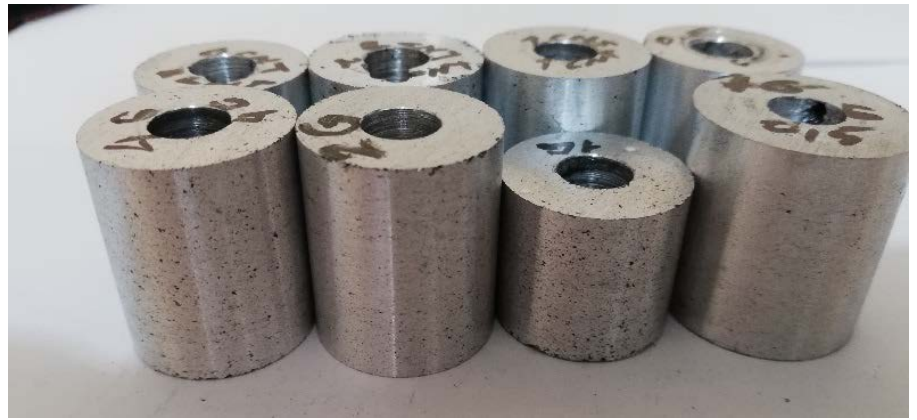

Şekil 3. Sekiz farklı takviye oranında üretilen kompozit numuneler

Daha sonra, hazırlanan nano malzeme takviyeli Al 2024 kompozit numuneler üzerinde planlanan deney ve incelemelere geçilmiştir. $\mathrm{Bu}$ amaçla ilk olarak talaşlı işleme deneyleri (ISO 3685, 1993)‘e uygun olarak yapılmıştır. Her işleme deneyi kullanılmamış yeni takım ucu ile yapılmış olup deneylerinde kesici takım olarak, Sandvik marka, SNMG120408-QM H13A kodlu Sementit Karbür (SK) uçlar kullanılmıştır. 
İşleme deneyleri sırasında işlenen yüzeyler ait pürüzlülük değerleri ölçülmüş ve aşınma davranışlarını optik mikroskopta incelenmek üzere, herbiri tek işleme deneyinde kullanılan kesici takım uçları kodlanmışıtr. İşleme deneyleri, kuru kesme şartlarında, $200 \mathrm{~m} / \mathrm{min}$ kesme hızında, üç farklı ilerleme değerinde $(0,05-0,10-0,20 \mathrm{~mm} / \mathrm{rev})$ ve $1 \mathrm{~mm}$ sabit kesme derinliğinde gerçekleştirilmiştir. İşleme deneyleri sırasında çekilen görüntü Şekil 4’te verilmektedir.

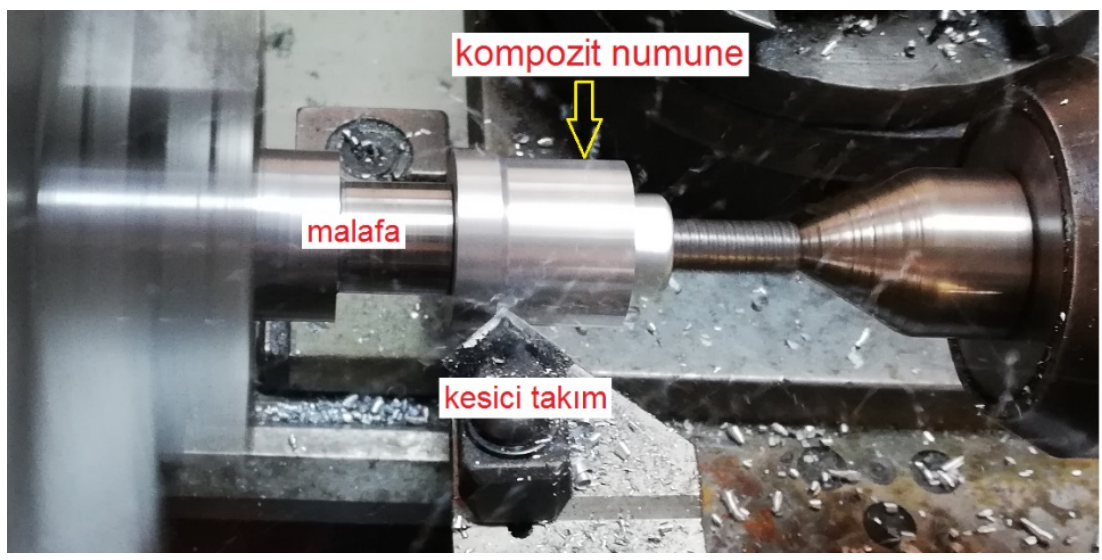

Şekil 4. İşleme deneyi ve kullanılan torna tezgahı

İ̧̧lenen yüzeylerin $R a$ cinsinden yapılan pürüzlülük ölçümlerinde, kompozit numunelerin yüzeyindeki 5 farklı bölgeden ölçümler yapılarak bu değerlerin aritmetik ortalamaları alınmıştır. Yüzey pürüzlülük ölçümlerinde (TS 6212 EN ISO 4288, 1999) standardından yararlanılmıştır.

İşlenebilirlik çalışmalarının diğer bir bölümünü ise kesici takım aşınmalarının incelenmesi oluşturmuştur. Bu amaçla kullanılan kesici takım uçları stereo mikroskop altında incelenmiştir. Her takım ucundan yan yüzey ve üstten olmak üzere görüntüler alınmıştır. İşleme deneylerinin tamamlanması ve buna bağlı olarak yapılan yüzey pürüzlülüğü ve takım aşınması incelemelerinden sonra, nano katkılı kompozit numunelerin bazı mekanik özelliklerini belirleyecek deney ve inceleme aşamasına geçilmiştir.

Bu amaçla ilk olarak numunelerin makro sertlik ölçümleri yapılmıştır. Sertlik ölçme işlemleri, Brinell yöntemi kullanılarak (TS EN ISO 4498, 2011) ve (TS EN ISO 6506-1, 2007) standartlarına uygun olarak, Qness Q250M model sertlik ölçme cihazında yapılmıştır. Sertlik ölçümlerinde $2,5 \mathrm{~mm}$ çaplı bilya uç, $62,5 \mathrm{~kg}$ yük ve 14 saniye deney süresi uygulanmıştır. Sertlik ölçümlerinde her numune üzerinde 5 farklı noktadan ölçüm yapılarak ortalama değer hesaplanmıştır.

Mekanik özellikleri belirleyecek deneylerin ikinci aşamasında kompozit numunelerin abrasif aşınma davranışları incelenmiştir. Aşınma deneyleri, $74 \mu \mathrm{m}$ aşındıııcı tane boyutuna sahip, $\mathrm{Al}_{2} \mathrm{O}_{3}$ zımpara kullanılarak, $10 \mathrm{~N}, 20 \mathrm{~N}$ ve $40 \mathrm{~N}$ yükler altında her numune için ayrı ayrı yapılmıştır. Kompozit numuneler, $0,6 \mathrm{~ms}^{-1}$ kayma hızında ve $40 \mathrm{~s}$ süre boyunca deneye tabi tutularak aşınma kayıpları kaydedilmiştir. Şekil 5’te aşınma deneyleri sırasında çekilmiş görüntüler verilmektedir.

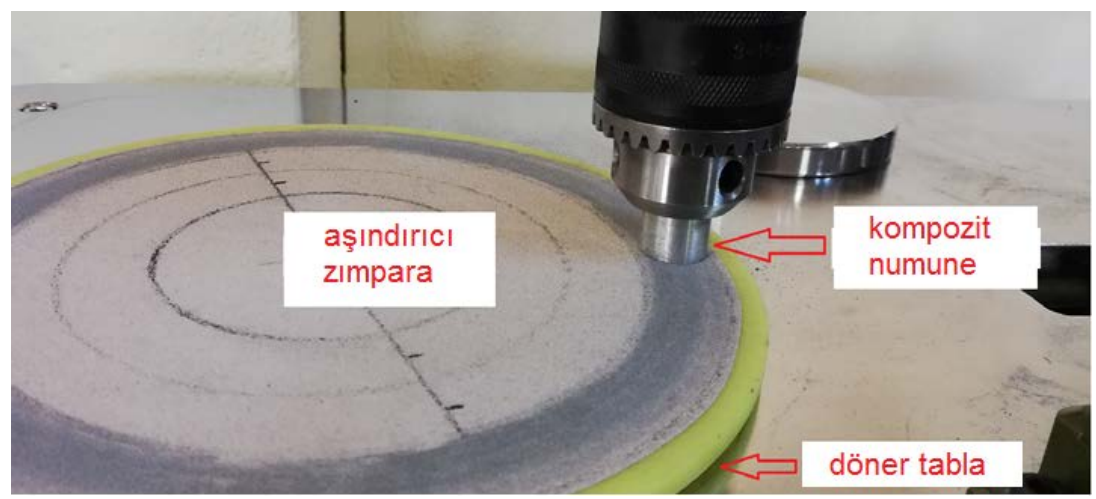

Şekil 5. Aşınma deney numuneleri, pin-on-disc aşınma deney cihazı ve aşınma deney anı

\section{SONUÇLAR VE TARTIŞMA}

\subsection{Kompozitlerin üretilebilirliği}

Nano malzeme katlı1ı AI2024 matrisli kompozit numuneler karıştırmalı döküm yöntemi kullanılarak üretilmişlerdir. Kaış̧ırma işlemi sırasında karbon nanotüp (CNT) ve grafen (G) takviye malzemelerinin erimiş haldeki sıvı metal içerisine karıştırılması işleminde zorluklar yaşanmıştır. Pota içerisine ilave edilen nano boyuttaki malzemenin eriyik bünyesinde dağılması için farklı karıştırma hızları ve süreleri denenmiş olmasına rağmen arzu edilen homojenlikte takviye dağılımı elde edilememiştir. Takviye malzemesinde topaklanmaların yaşandığı özellikle de takviye oranının \% 1,0'in üzerine çımasıyla bu durumun daha belirgin 
hale geldiği üretimi yapılan kompozit numunelerin yüzey görüntülerinden anlaşılmıştır. Bu tür nano malzeme katkılı metal matrisli kompozitlerin üretiminde, infiltrasyon veya toz metalurjisi gibi yöntemlerin kullanılarak, sonuçların karıştırmalı döküm yöntemiyle mukayese edilmesi tavsiye edilebilir.

\subsection{Sertlik sonuçlarının değerlendirilmesi}

Kompozit numunelerin, takviye oranlarına göre ölçümünden elde edilen sertlik değerlerine göre çizilen grafikler Şekil 6'da gösterilmektedir.

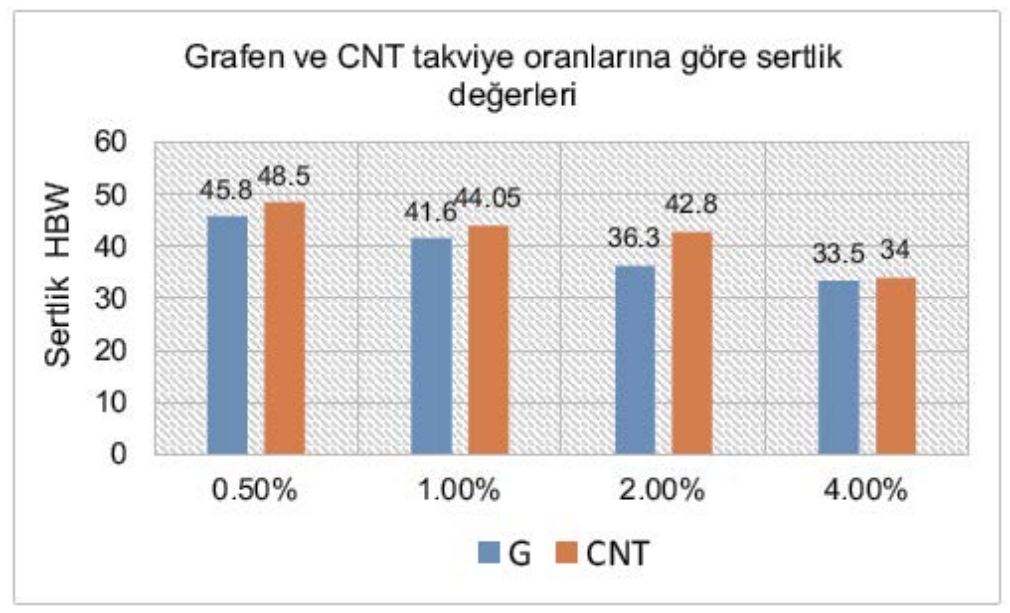

Şekil 6. Nano kompozitlerin sertlik değerleri

Şekil 6'daki grafikler incelendiğinde ilk göze çarpan, nano malzeme takviye miktarlarının artışına bağlı olarak sertlik değerlerindeki azalma eğilimidir. Bu durum hem G hemde CNT takviyeli kompozit numunelerde aynı şekilde gelişmiştir. Nano malzeme takviye miktarındaki artış ile kompozit yapıdaki takviye dağılımının homojenliği giderek bozulmuş ve büyük oranda takviye topaklanmaları meydana gelmiştir. Takviye topaklanmaları beraberinde porozite ve yapı içerisinde boşluk oluşumuna neden olmuştur. Bu durum, kompozitlerin sıvı faz üretim yöntemindeki yetersizlik ile açıklanabilir. Daha önceki bölümlerde de ifade edildiği gibi karıştırmalı döküm yöntemi ile sıvı fazdaki AI 2024 malzeme içerisine nano boyuttaki takviye elemanlarının karıştırılarak homojen dağıtılmasında istenilen seviyede başarı sağlamak mümkün olamamıştır. Takviye miktarının artmasıyla geniş topaklanma bölgeleri meydana gelmiş ve zaten yumuşak fazda olan nano malzemeler kompozit yapının yumuşamasına sebep olmuştur.

G (grafen) takviyeli kompozitlerde CNT (karbon nanotüp) takviyeli kompozitlere göre bütün takviye oranlarında daha yumuşak değerler ölçüldüğü görülmektedir. Bu durum kompozit yapı içerisinde, G nano malzemelerin düzlemsel ağ yapısının, CNT’nin içi boş silindirik yapısına göre daha geniş yüzey alanına dağılım sergilemesiyle açıklanabilir. Dolayısıyla bütün takviye oranlarında G takviyeli kompozitler daha yumuşak kalmıştır. En yüksek sertlik değeri 48,5 HBW ile \%0,5 CNT takviyeli kompozitte ölçülürken, en düşük sertlik değeri $34 \mathrm{HBW}$ ile \%4,0 G takviyeli kompozitte ölçülmüştür.

\subsection{Aşınma sonuçlarının değerlendirilmesi}

Kompozit numunelerin, pin-on-disc yöntemi ile yapılan aşınma deneylerinden takviye cinsi ve takviye oranlarına göre elde edilen aşınma kaybı değerlerine göre çizilen grafikler Şekil 7’de gösterilmektedir.

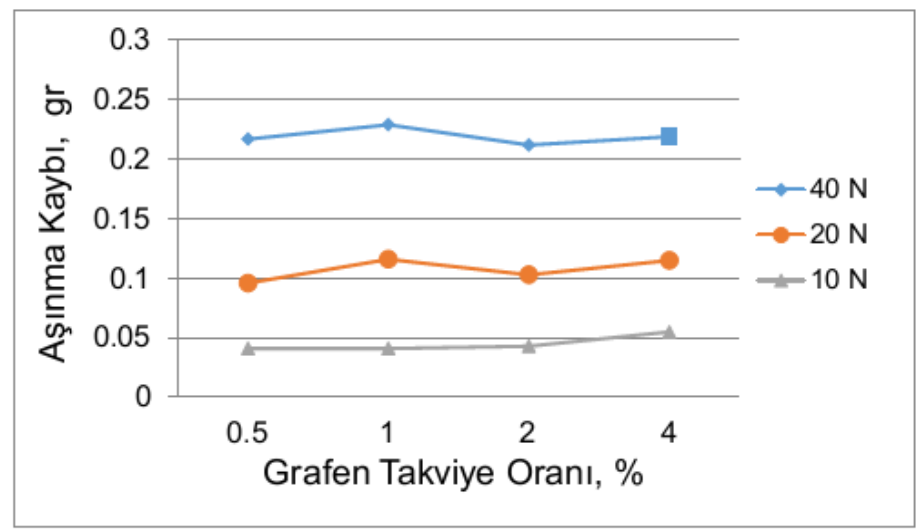




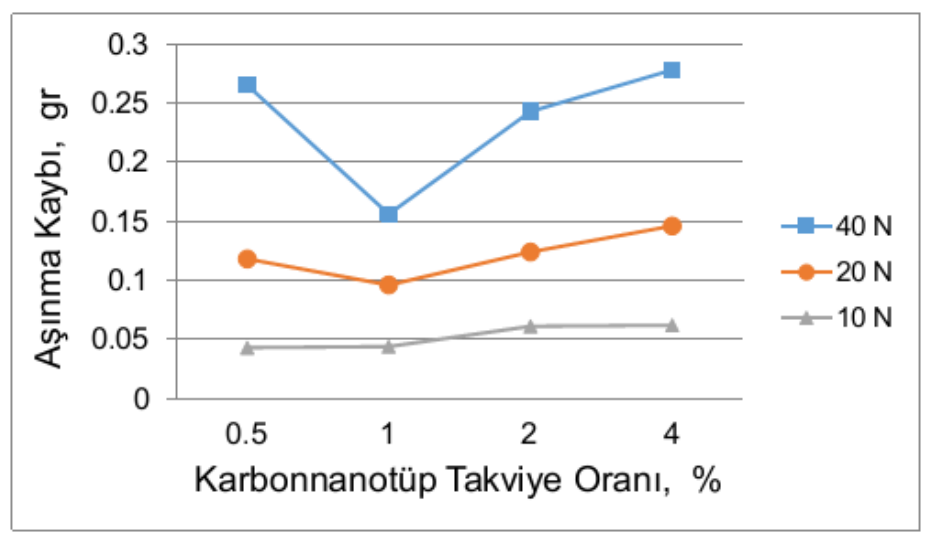

Şekil 7. Nano takviyeli kompozit numunelerin abrasif aşınma miktarları

Şekil 7'deki grafiklere bakıldığında genel olarak her üç yük miktarında da takviye oranlarının artmasıyla aşınma kayıplarının da artış gösterdiği görülmektedir. Genel olarak CNT takviyeli kompozitlerdeki aşınma kayıpları bir miktar fazla olsada, G takviyeli kompozitlere yakın değerlerde seyretmiştir. Ancak grafiklerdeki genel seyrin aksine, CNT takviyeli kompozit numunede \%1,0 takviye oranındaki aşınma kaybı, \% 0,5 takviyeye göre daha az meydana gelmiştir. Bu durumun kompozit numunenin üretiminden kaynaklandığını söylemek mümkündür. Daha önceki değerlendirmelerde de vurgulandığı gibi kompozit yap1 içerisinde takviye malzemelerinin homojen dağılımı çok mümkün olamamıştır. Dolayısıyla aşınma deneylerinde, \%1,0 CNT takviyeli kompozitin aşındırılan yüzeyine, yapının tamamında görülen düzensiz dağılımın aksine daha homojen ve kararlı bir kompozit yapı denk gelmiş olabilir. Veya bu bölgede nano takviye malzemesi çok az dağılmış olabilir ve buna bağlı olarak boşluklu yapı daha az oluşmuş olabilir. Sonuç olarak bu takviye oranına sahip kompozit numunede daha az aşınma değeri ölçülmüştür. Kompozitlerin aşınma davranışlarını daha iyi değerlendirebilmek için $40 \mathrm{~N}$ yük ile yapılan deneylerden sonra aşınan yüzeylerden çekilen mikroskop görüntüleri Şekil 8’de verilmektedir.

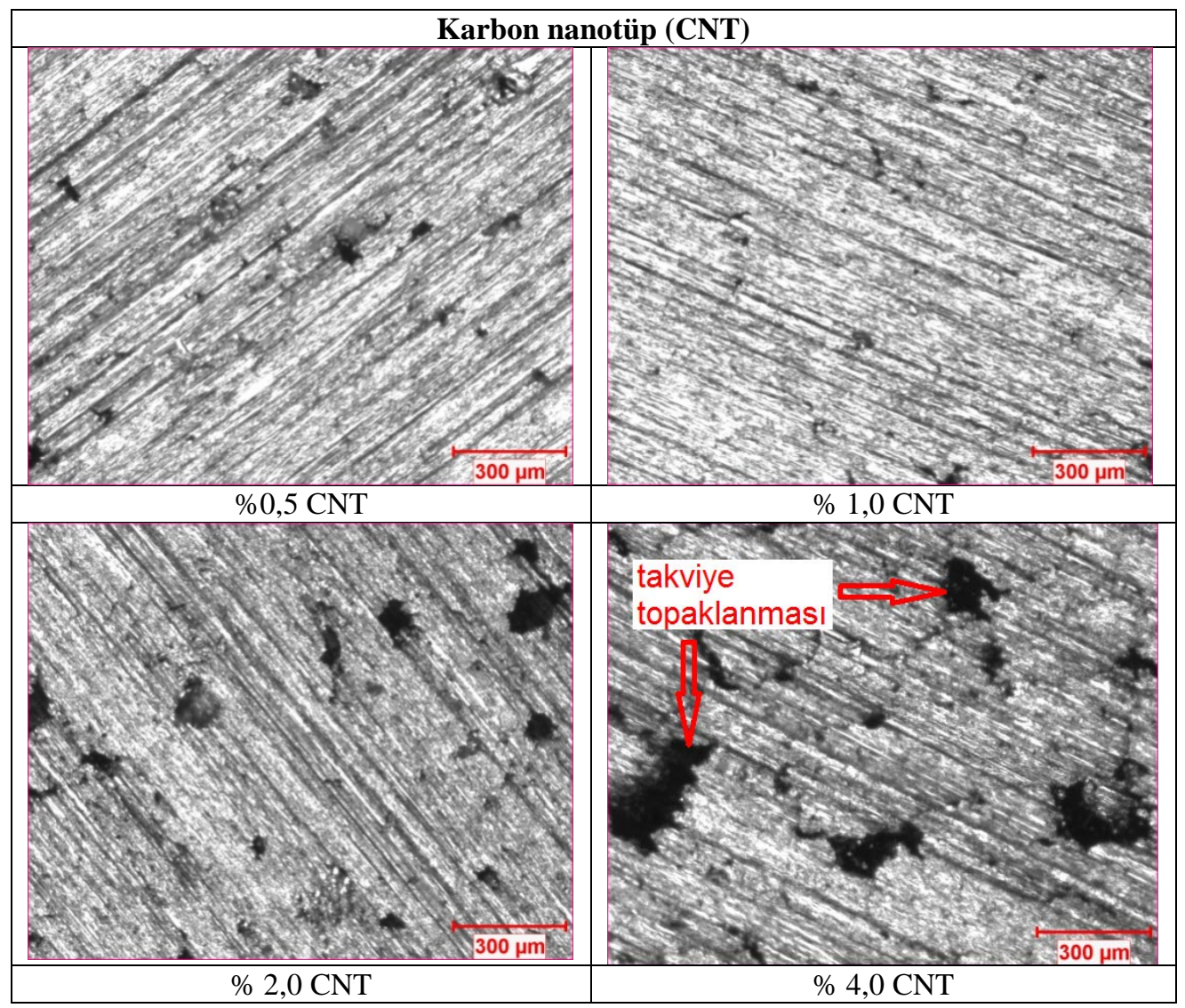

Şekil 8. CNT ve G takviyeli AI 2024 matrisli kompozit numunelerin aşınma güzeyleri 


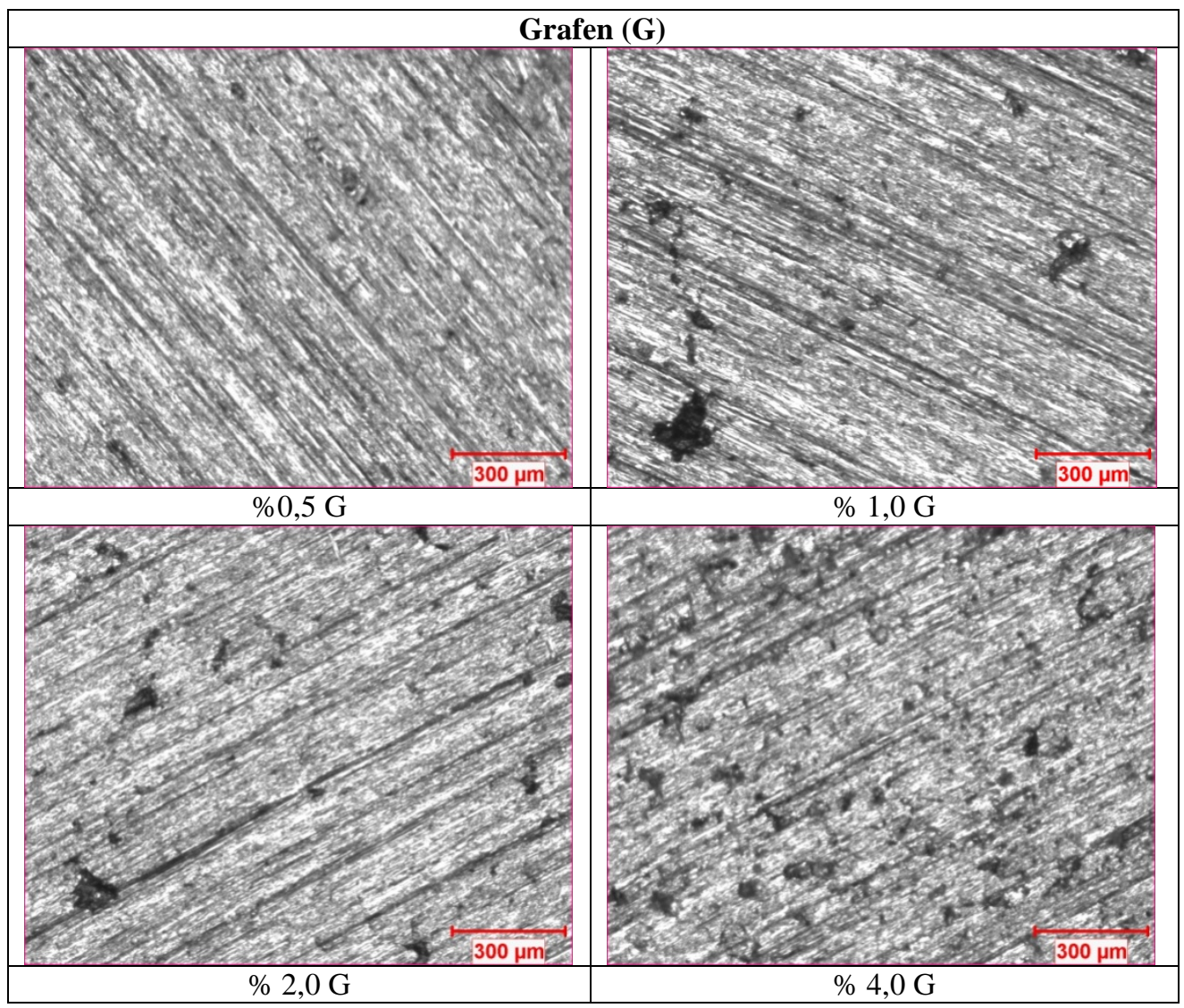

Şekil 8 (devam). CNT ve G takviyeli AI 2024 matrisli kompozit numunelerin aşınma güzeyleri

Şekil 8'deki mikroskop görüntüleri incelendiğinde, takviye elemanı olan nano malzemelerin topaklanmalar oluşturduğu ve alüminyum matris içerisinde düzensiz dağılım sergilediği görülmektedir. Takviye oranının artışına bağlı olarak bu olumsuz durumun daha fazla öne çıktığı anlaşılmaktadır. Kompozitlerin üretim yönteminde kullanılan karıştırmalı döküm tekniği ile nano boyuttaki parçacıkların homojen dağılımını temin etmek mümkün olamamıştır. Özellikle CNT takviyeli kompozit numunelerde bu durum $\mathrm{G}$ takviyeli kompozitlere göre daha belirgindir.

Yüzeyler üzerindeki aşınma çizgileri genel olarak birbirine yakın özellikte meydana gelmiştir. Matris malzemesi AI 2024 içerisinde topaklanan CNT ve G takviye malzemelerinin aşınma deneyleri sırasında yüzeyi yer yer terk ettiği ve boşluklar oluşturduğu söylenebilir. Özellikle \% 2,0 ve \% 4,0 takviye oranlarında boşluklu yapı daha fazla öne çıkmıştır. Bu duruma bağlı olarak CNT takviyeli kompozitlerdeki aşınma kayıpları \% 1,0 takviye oranından başlıyarak giderek artış göstermiştir.

Grafen takviyeli kompozit numunelerdeki aşınma kaybı değerleri ile aşınma yüzeyi görüntüleri arasında bağ kurulabilir. G takviyeli kompozitlerin aşınma yüzey görüntülerine bakıldığında en fazla takviye topaklanmasının $\% 1,0 \mathrm{G}$ takviyeli numunede olduğu görünmektedir. Dolayısıyla da yapı içerisindeki bu topaklanmaya bağlı olarak takviyenin yüzeyden uzaklaşması ve boşluklu yapıya sebep olması kaçınılmaz olmuştur. Ayrıca, aşınma yüzeylerindeki bazı derin çiziklerin oluşmasına, deneyler sırasında $\mathrm{AI}_{2} \mathrm{O}_{3}$ zımparadan kopan aşındırıcı parçacıkların neden olduğu ifade edilebilir. Sonuç olarak AI 2024 matris malzemesi içerisine ilave edilen nano CNT ve G takviye malzemelerinin kompozit yapının aşınma direncini düşürerek olumsuz etkilediği tespit edilmiştir.

\subsection{Yüzey pürüzlülüklerinin değerlendirilmesi}

Kompozit numunelerin, işleme deneylerinden sonra yüzeylerinden ölçülen $R a$ cinsinden pürüzlülük değerlerine göre çizilen grafikler Şekil 9'da gösterilmektedir. 


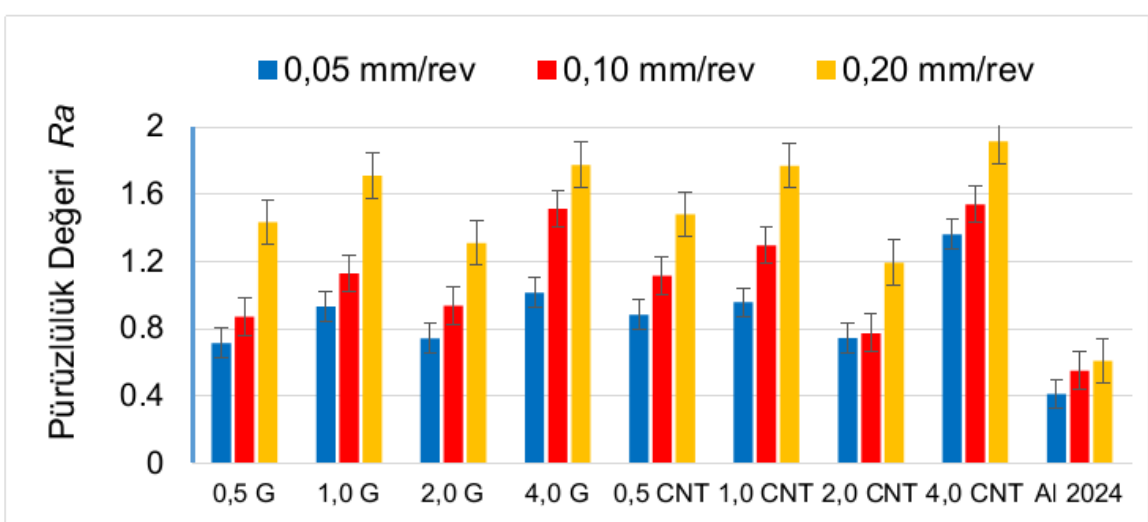

Takviye Oranları \%

Şekil 9. İlerleme değeri ve takviye oranlarına göre yüzey pürüzlülükleri

Şekil 9'daki grafiğe bakıldığında ilk göze çarpan, ilerleme değerindeki artışla birlikte tüm kompozit numunelerdeki yüzey pürüzlülük değerlerinin artış göstermesidir. İkinci önemli tespit ise nano malzeme katkısız AI 2024 malzemedeki yüzey pürüzlülük değerlerinin katkılı kompozit malzemelere göre yarıya yakın miktarda düşük olmasıdır. Çok basit bir ifadeyle, nano malzeme katkısının AI 2024 malzemede yüzey pürüzlülük değerlerini arttırdığı ve bu yönüyle yüzey kalitesini olumsuz etkilediği görülmüştür. Aşınma yüzeylerinden çekilen mikroskop görüntülerinden anlaşılacağı üzere nano malzemeler kompozit yap1 içerisinde homojen dağılım sergileyememiş ve oluşan takviye topaklanmaları sebebiyle yüzey kalitesi bozulmuştur. Talaş kaldırma esnasında takviye topaklanmalarının olduğu yüzey bölgelerinde, kesici takım ucu gözenekle veya grafit esaslı takviye malzemelerinin yoğun olarak toplandığ 1 yumuşak faz ile karşılaşıı̆ında pürüzlülüğün oluşmasına sebep olmuştur. Diğer bir ifadeyle, takviye topaklanması olan bölgelerde takviyenin koparak yüzeyden uzaklaşması sebebiyle gözenekli veya boşluklu yüzey meydana gelmiştir. Grafiğe bakıldığında genel olarak, CNT takviyeli kompozit numunelerdeki yüzey pürüzlülük değerlerinin G (grafen) takviyeli numunelere göre bir miktar daha fazla olduğu söylenebilir. Bu durum, grafenin plaka halindeki yapısına karşın, CNT'nin içi boş silindirik yapıda olması ile ifade edilebilir. Bu iki nano malzeme temelde karbon atomları olmasına rağmen, aralarındaki yapısal farklılık yüzey pürüzlülük değerlerinde de bir miktar fark yaratmıştır. Şekil 9'daki grafik incelendiğinde, genel olarak 3 ilerleme değerinde de $\% 2$ nano malzeme takviyeli numueler en düşük pürüzlülük değerlerini sergilemiştir. Takviye miktarları $\% 0,5^{\prime}$ ten $\% 1,0$ 'e çıkarken artış göstermiş, $\% 1,0$ 'den $\% 2,0$ 'ye çıkarken azalmış, $\% 2,0$ 'den $\% 4,0$ 'e çıkarken tekrar artışa geçerek en yüksek değerine ulaşmıştır. Kompozit yapı içerisindeki nano malzeme katkı miktarlarının artmasıyla, yüzey pürüzlülük değerleri de lineer bir artma göstermemiştir. Bu durumda, \% 2,0 nano malzeme katkısının butün kompozit yapılarda işlenebilirlik açısından uygun bir oran olduğu söylenebilir. Zira, hem CNT hem de G takviyeli numunelerde aynı şekilde en düşük yüzey pürüzlülük değeri \% 2,0 takviye oranında elde edilmiştir.

CNT nano malzeme ile $\mathrm{G}$ nano malzeme arasındaki pürüzlülük değerlerindeki farkları ve \% 2,0 takviyeli numunelerin pürüzlülük değerlerini daha açık görebilmek için Şekil 10 'da üç ilerleme değerine göre, nano malzemelerin yüzey pürüzlülük değerlerini ayrı ayrı gösteren grafikler toplu olarak verilmektedir.

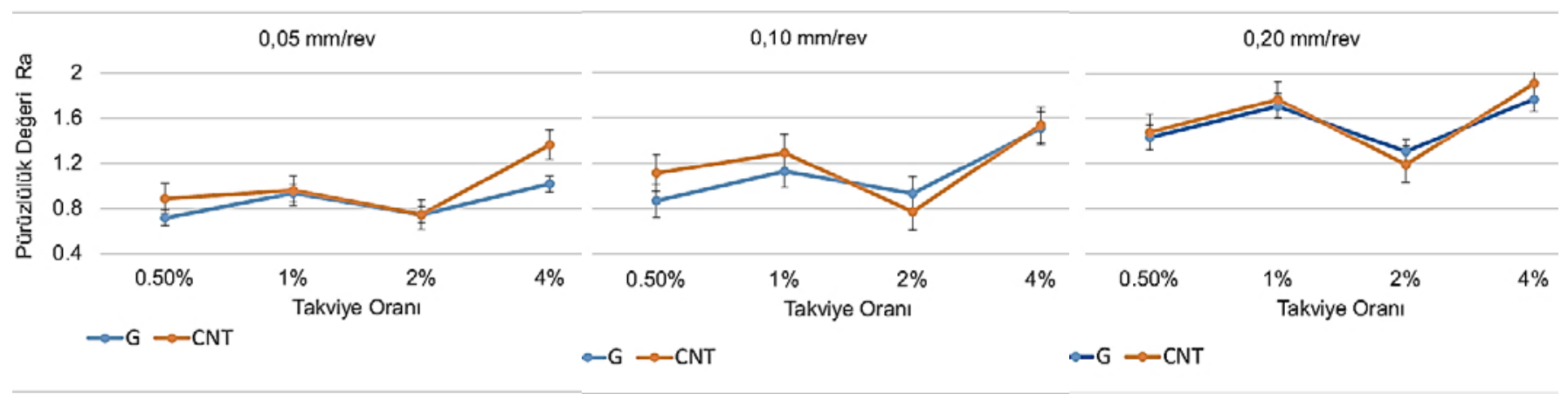

Şekil 10. İlerleme değerlerine göre CNT ve G takviyeli kompozitlerdeki yüzey pürüzlülükleri

Şekil 10'daki grafikler incelendiğinde CNT takviyeli numunelerin pürüzlülük değerlerinin G takviyeli numunelere göre biraz daha fazla olduğu görülmektedir. Ayrıca her iki nano malzeme takviyeli kompozitte de \% 2,0 takviye oranlarında en düşük pürüzlülük değerleri elde edilmiştir. Yukarıda da ifade edildiği gibi \% 2,0 takviye oranı bu tür kompozitlerde optimum oran olarak kabul edilebilir.

\subsection{Takım aşınmalarının değerlendirilmesi}

İşleme deneylerinden sonra kesici takımların stereo mikroskopta çekilen görüntüleri Şekil 11 ve 12 'de verilmiştir. 


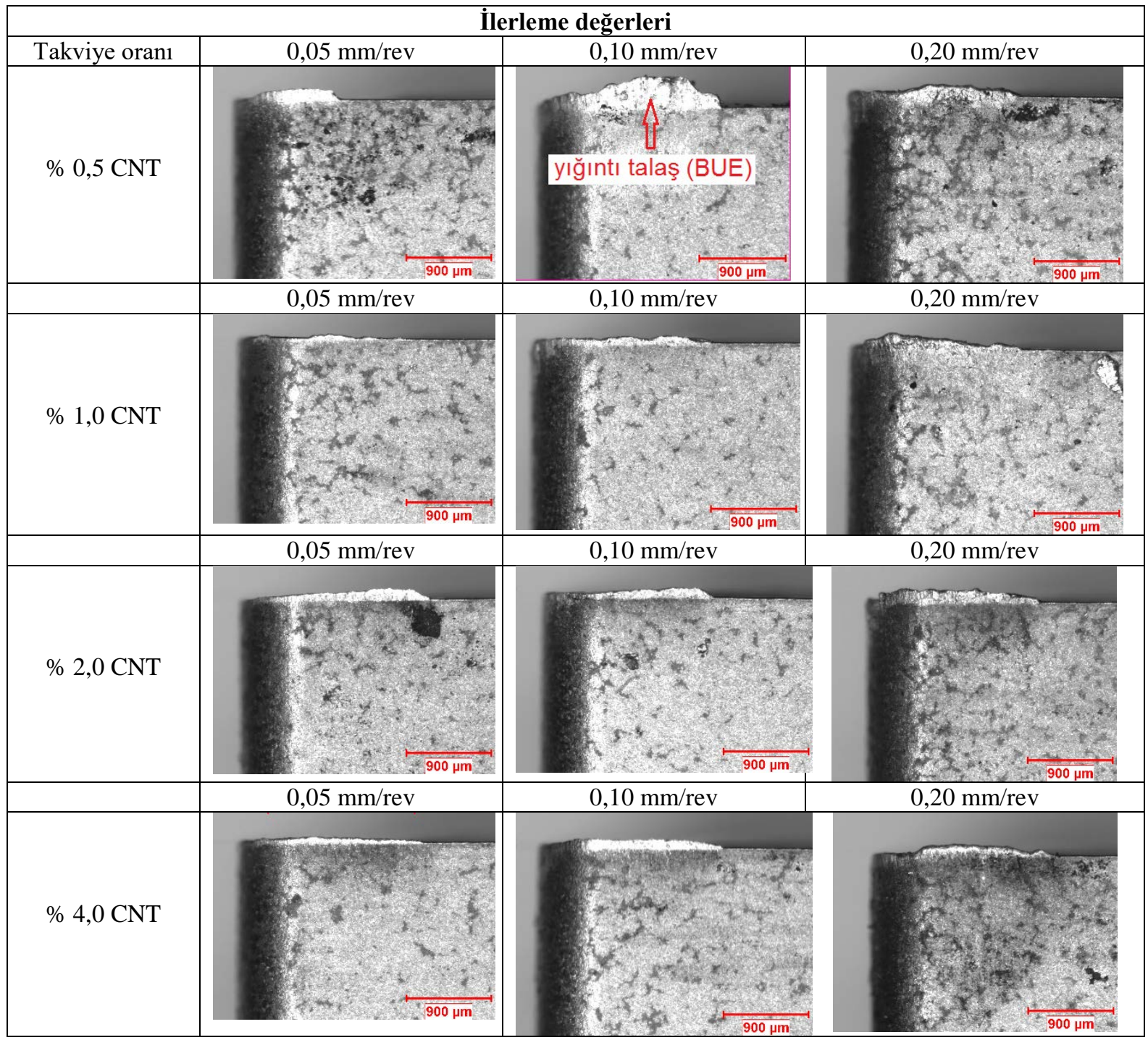

Şekil 11. CNT takviyeli kompozitlerin işlenme deneylerinde kullanılan kesici takımlar

Şekil 11'deki mikroskop görüntülerine bakıldığında kesici takımların tamamında yan yüzey aşınmasının meydana gelmediği söylenebilir. Deneylerde seçilen kesme hızı ve ilerleme değerleri, takım uçlarında herhangi bir aşınma olmamış ancak kesici takımların tamamında bir miktar yığıntı talaş (BUE) oluşumuna sebep olmuştur. Kompozit malzemenin yapısında bulunan takviye malzemesinden çok az miktarda takım yan yüzeylerine yapıştı̆̆ı görünmektedir. Alüminyum gibi sünek malzemelerin işlenmesinde ortaya çıkan yığıntı talaş bu deneylerde de takım yüzeylerinde meydana gelmiştir. Ancak ilerleme değerinin artmasıyla yığıntı talaş miktarında artış oluşmamışıtır. Bunun sebebi olarak, kompozit malzeme içerisindeki takviye elemanı CNT partiküllerinin homojen olmayan dağılımını göstermek mümkündür. Diğer mekanik deneylerde olduğu gibi kararsız takviye dağılımı ve meydana gelen boşluklu yapı nedeniyle işleme deneyleri sırasında kesici takım ucu farklı malzeme fazlarıyla karşılaşmıştır. Dolayısıyla takviyesiz bir alüminyum malzemenin işlenmesinde ve genelde ilerleme değerinin artışına bağlı olarak lineer biçimde artması beklenen yığıntı talaş miktarı, bu deneylerde oluşmamıştır. 


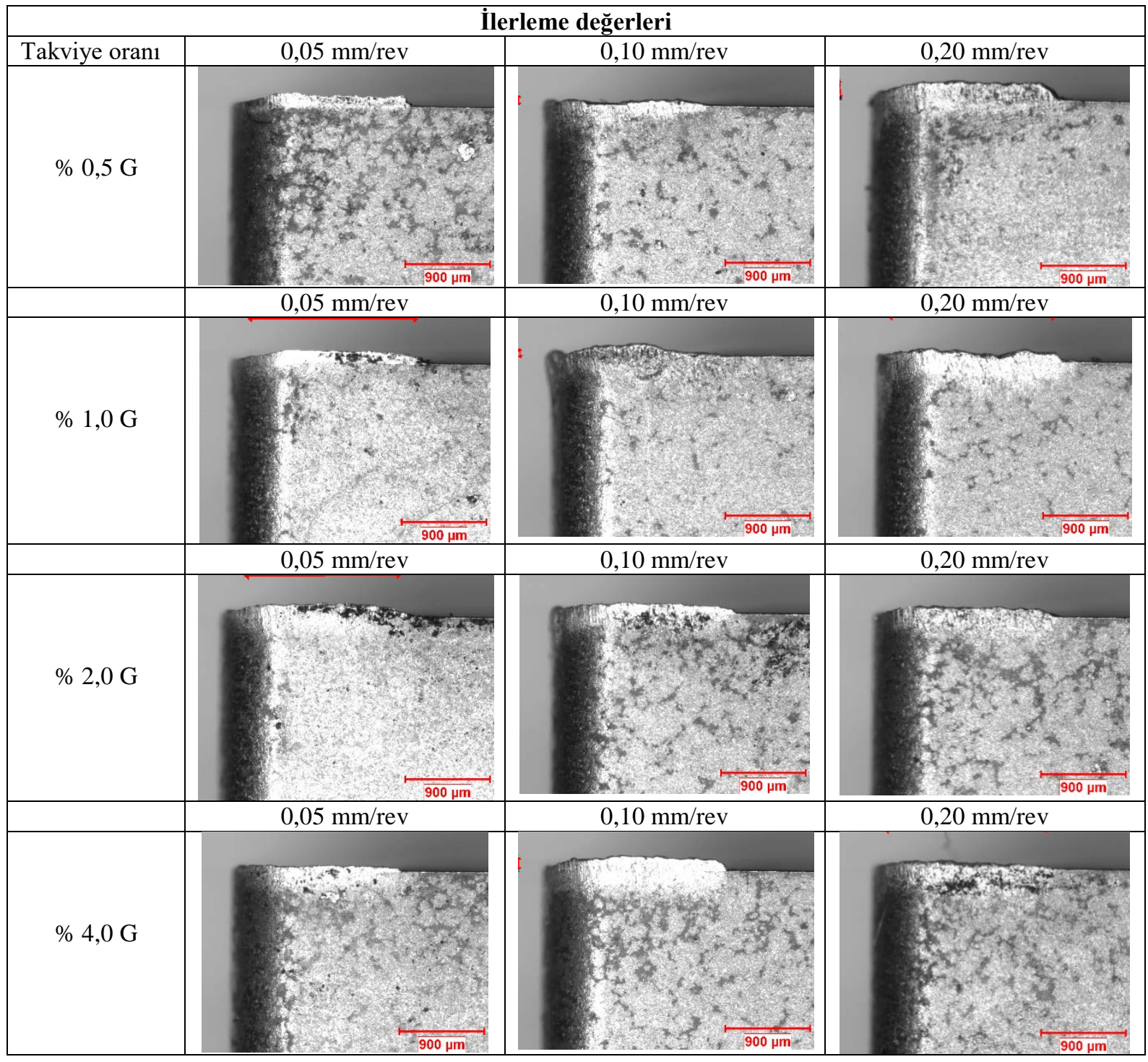

Şekil 12. G takviyeli kompozitlerin işlenme deneylerinde kullanılan kesici takımlar

Şekil 12'deki görüntüler incelendiğinde, Şekil 11'deki gibi G takviyeli kompozit numunelerin işleme deneylerinde kullanılan kesici takımlarda da yan yüzey aşınması meydana gelmemiștir. Ancak, CNT katkılı numunelerin işlendiği kesici takımlarda olduğu gibi yığıntı talaş oluşumu gözlenmektedir. Yığıntı talaş miktarlarının, CNT takviyeli numunelerin işlendiği kesici takımlardan biraz daha fazla olduğu söylenebilir. Bu durumu, G takviyeli kompozitlerin CNT takviyeli kompozitler göre daha düşük sertlik değerlerinde olmasıyla ve tabaka şeklindeki atomik yapısıyla açılamak mümkün olabilir. Sonuç olarak, işleme deneyleri için seçilen kesici takım ve kesme parametrelerinin, bu tür kompozit yapıların işlenmesinde, takım aşınması yönünden uygun olduğu görülmüştür.

Mukayese yapabilmek amacıyla nano malzeme takviye edilmemiş AI 2024 malzemenin işlenmesinde kullanılan kesici takım uçlarının mikroskop görüntüleri Şekil 13 'te verilmiştir. 


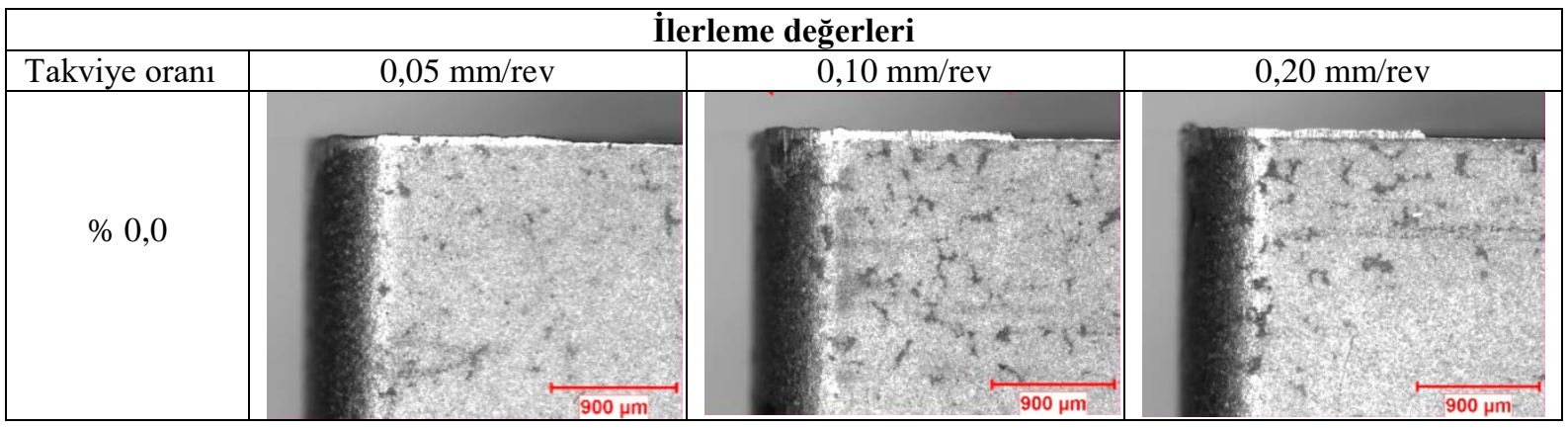

Şekil 13. Nano malzeme takviye edilmemiş AI 2024 malzemenin işlenme deneylerinde kullanılan kesici takımlar

Şekil 13'teki takım görüntülerine bakıldığında, üç farklı ilerleme değerinde de takım uçlarında herhangi takım aşınması meydana gelmediği görülmektedir. Çok az miktarda yığıntı talaş oluşmuştur. Ancak yığıntı talaş miktarları CNT ve G nano malzeme takviyeli kompozit numunelere göre oldukça az miktarlardadır. Daha öncede ifade edildiği gibi sünek yapıda olan AI 2024 malzemenin işlenmesinde bir miktar BUE oluşması beklenen bir sonuçtur. Burada dikkat çekilmesi gereken husus, hem CNT hem de G takviye malzemelerinin takım yüzeylerinde BUE oluşumuna katkı sağlamasıdır. Grafit atomlarından meydana gelen bu iki tür nano malzemenin, katkıdıkları yapılara kayganlığın yanında bir miktar yapışma özelliği de kazandırmış oldukları söylenebilir. Dolayısıyla bu deneysel çalışmada, içerisine nano boyutta CNT ve G takviye edilen alüminyum malzemenin işlenmesinde takım yüzeylerinde normalden daha fazla yı̆̆ıntı talaş oluşmuştur. Kesici takım takım yüzeylerinde oluşan yığıntı talaşlar, takım aşınmasına neden olmamıştır ancak işlenen kompozit numunelerin yüzeylerinden ölçülen pürüzlülük değerlerinde etkili olduğu değerlendirilmiştir.

\subsection{Sonuçlar}

Yapılan deneysel çalışmadan elde edilen sonuçlar aşağıda sıralanmıştır:

- Karıştırmalı döküm yöntemi kullanılarak elde edilen nano malzeme takviyeli kompozitde istenilen homojenlikte takviye dağılımı elde edilememiştir. Bu tür nano malzeme katkılı metal matrisli kompozitlerin üretiminde, infiltrasyon veya toz metalurjisi gibi farklı yöntemlerin kullanılarak, sonuçların karıştırmalı döküm yöntemiyle mukayese edilmesi tavsiye edilebilir.

- Kompozit yapı içerisine katılan CNT ve G takviye malzemerinde topaklanmaların yaşandığı, özellikle de takviye oranının \% 1,0'in üzerine çıkmasıyla bu durumun daha belirgin hale geldiği tespit edilmiştir.

- Hem G hemde CNT takviyeli kompozit numunelerde takviye miktarlarının artışına bağlı olarak sertlik değerleri azalmıştır. G takviyeli kompozitlerde CNT takviyeli kompozitlere göre bütün takviye oranlarında daha düşük sertlik değerleri ölçülmüştür. $\mathrm{Bu}$ duruma kompozit yapı içerisindeki, G nano malzemelerin düzlemsel ağ yapısının, CNT’nin içi boş silindirik yapısına göre daha geniş yüzey alanına dağılmış olmasının neden olduğu düşünülmektedir.

- Genel olarak üç aşınma yük miktarında da (10, 20, 40 N) CNT ve G takviye oranlarının artmasıyla, aşınma kayıplarıda artış göstermiştir. AI 2024 matris malzemesi içerisine ilave edilen nano CNT ve G takviye malzemelerinin kompozit yapının aşınma direncini düşürerek olumsuz etkilediği tespit edilmiştir. Bu sonucu sertlik sonuçlarıyla birlikte değerlendirmek mümkündür.

- İşleme deneylerinde beklendiği şekliyle, ilerleme değerindeki artışla birlikte tüm kompozit numunelerdeki yüzey pürüzlülük değerleri artış göstermiştir. Ancak nano malzeme katkısız AI 2024 malzemedeki yüzey pürüzlülük değerleri, CNT ve G katkılı kompozit malzemelere göre yarıya yakın miktarda düşük ölçülmüştür. Nano malzeme katkısı AI 2024 malzemede yüzey pürüzlülük değerlerini arttırarak yüzey kalitesini olumsuz etkilemiştir. Genel olarak, CNT takviyeli kompozit numunelerdeki yüzey pürüzlülük değerlerinin, G takviyeli numunelere göre bir miktar daha fazla olduğu söylenebilir.

- İşleme deneylerinde seçilen kesme parametreleri, kullanılan kesici takım uçlarının tamamında, herhangi bir aşınma mekanizmasına neden olmamıştır. Ancak kesici takımların tümünde bir miktar yığıntı talaş (BUE) oluşumuna sebep olmuştur. $\mathrm{Bu}$ yığıntı talaşların, takım aşınmasına neden olmadığı ancak, kompozit numunelerin yüzey pürüzlülük değerlerinde etkili olduğu değerlendirilmiştir. Sonuç olarak, işleme deneyleri için seçilen kesici takım ve kesme parametrelerinin, bu tür kompozit yapıların işlenmesinde, takım aşınması yönünden uygun olduğu görülmüştür.

\section{TEŞEKKÜR}

Bu çalışma, 2017/076 numaralı proje kapsamında Kırıkkale Üniversitesi BAP Birimi tarafından desteklenmiştir. 


\section{REFERANSLAR}

C. M. Şenel, M. Gürbüz, E. Koç (2015). Grafen Takviyeli Alüminyum Matrisli Yeni Nesil Kompozitler. Mühendis ve Makina, Cilt 56, Say1 669, 36-47.

H. Aydın ve A. Bayram (2010).Farklı Isıl İşlem Koşullarındaki 2024 Aluminyum Alaşımlarının Korozyon Sonrası Mekanik Özelliklerindeki Kaybın Belirlenmesi. Uludağ Üniversitesi Mühendislik-Mimarlık Fakültesi Dergisi, Cilt 15, Sayı 1, $159-168$.

ISO 3685 (1993). Tool-life testing with single-point turning tools, 1-12.

İ. Mutlay(2014). Karbon Nanotüpler: Özellikler ve Uygulamalar. Grafen Chemical Industries Co. Ankara, Turkey.

K. Dharsan, S. Santhosh Kumar(2017). An Exploration of the Influence in Aluminium Metal Matrix Composite Reinforced with Graphene.5thNational Conference on Trends in Automotive Parts Systems and Applications (TAPSA-2017), International Journal of Innovative Research in Science, Engineering and Technology, Vol 6, Special Issue 7, 141-142.

S. R. Bakshi, D. Lahiri ve A. Agarwal(2010). Carbon nanotube reinforced metal matrix composites - A Review. International Materials Reviews, Vol 55, No 1, 41-61.DOI:10.1179/095066009X12572530170543

TS 6212 EN ISO 4288(1999). “Mamulün Geometrik Özellikleri (Gps) - Yüzey Yapısı: Profil Metodu - Yüzey Yapısının Değerlendirilmesi İçin Kurallar ve İşlemler. TSE, Ankara.

TS EN ISO 4498(2011). "Sinterlenmiş metal malzemeler (sert metaller hariç) - Görünen sertliğin ve mikrosertliğin tayini. TSE, Ankara.

TS EN ISO 6506-1(2007). “Metalik malzemeler - Brinell sertlik deneyi - Bölüm 1: Deney metodu. TSE, Ankara. 